\title{
Considerations on the Hematologic Toxicity of the all IC-BFM 2002/2009 Therapeutic Protocol in Children with Acute Lymphoblastic Leukemia
}

\author{
CRISTINA ELENA SINGER ${ }^{1 \#, ~ S O R I N ~ N I C O L A E ~ D I N E S C U ², ~ D I A N A ~ R O D I C A ~ T U D O R A S C U 3 *, ~ C R I S T I N A ~ F L O R E S C U, ~}$ \\ VENERA CRISTINA DINESCU ${ }^{5 *}$, ILEANA PUIU ${ }^{1}$, VERONICA CALBOREAN ${ }^{4}$, DIANA-MARIA TRASCA ${ }^{6}$ \\ 'University of Medicine and Pharmacy of Craiova, Pediatrics Department, 2 Petru Rares Street, 200349, Craiova, Romania \\ 2University of Medicine and Pharmacy of Craiova, Epidemiology and Primary Health Care Department, 2 Petru Rares Str., 200349 \\ Craiova, Romania \\ 3University of Medicine and Pharmacy of Craiova, Internal Medicine Department, 2 Petru Rares Str., 200349 Craiova, Romania \\ 4University of Medicine and Pharmacy of Craiova, Cardiology Department, 2 Petru Rares Str., 200349 Craiova, Romania \\ ${ }^{5}$ University of Medicine and Pharmacy of Craiova, Health Promotion and Occupational Medicine Department, 2 Petru Rares Str., \\ 200349 Craiova, Romania \\ Eniversity of Medicine and Pharmacy of Craiova, $2^{\text {nd }}$ Department of Medical Specialities, 2 Petru Rares Str., 200349, Craiova, \\ Romania
}

Acute lymphoblastic leukemia (ALL) is the most frequent malign hematologic disease in children. We studied the hematologic toxicity caused by the cytostatic treatment which was administered to the children diagnosed with ALL, according to the ALL-IC-BFM 2002/2009 protocol. The study included a number of 15 children with ALL who were treated from 2008 to 2018 within the Oncopediatrics Department of the $2^{\text {nd }}$ Pediatric Clinic of the Emergency County Hospital in Craiova. We decided upon the level of toxicity in blood values, taking into account the severity level $(G)$, according to the Common Terminology Criteria for Adverse Events 2010 guideline and we calculated the mean value of the hemoglobin, leukocytes, neutrophils, and thrombocytes in the children with ALL, for every phase of the cytostatic treatment. The most severe toxicity (grade 4 of severity) was registered in neutrophils (7/15 patients), during the induction and re-induction periods; 4 of these patients had severe infections.

Keywords: hematological toxicity, polichemotherapy protocols, acute lymphoblastic leukemia, children

Acute lymphoblastic leukemia (ALL) is the most common childhood cancer and represents $80 \%$ of all leukemia cases $[1,2]$.

The basic treatment is represented by antileukemic polychemotherapy. There has been a significant increase of life expectancy in children who were diagnosed with $A L L$ in the last couple of years due both to the large administered dosage of chemotherapy agents and to the supporting treatment [3].

Cytostatics - besides eliminating the malignant cloneinhibits normal tissues proliferation as well, especially those with speedy proliferation such as the hematopoietic tissues, reducing the number of pluripotent stem cells. Hematopoietic medulla will become hypo-cellular on the 3 cell lines (erythrocytic, megakaryocytic and granulocytic) and pancytopenia will occur in the peripheral blood.

Myelosuppression is directly linked to dosage and is transient most frequently (medulla recovers after 2-4 weeks) but repeated toxic aggression can determine aplasia, sometimes irreversible medullar aplasia. The peripheral pancytopenia may occur when the capacity of the pluripotent stem cell regeneration has decreased, after repeated toxics, under the threshold of $10 \%$ necessary for supporting the compartment of the hematopoietic precursors. Any previous cytostatic treatment determines the shortage of the occurrence interval for the pancytopenia and the prolonging of the recovery time [4]. It may be possible the existence of an individual sensitivity determined by a genetic or acquired deficit in some cytostatics elimination or detoxification [5, 6]. The chronic pancytopenia appears when continuously using cytotoxic drugs to destroy the microscopic neoplasia disease with the risk of recurrence or metastasis.

Cytostatics which most frequently induce medullar toxicity are: antimitotics (Vincristine), antimetabolites (Methotrexate, 6 Mercaptopurinum, 6-Thioguanina, Cytarabinum), alkilants (Cyclophosamide), antineoplasia antibiotics (anthracyclines - Adriamycin, Daunorubicine) and enzymes (L-Asparaginase) [7].

\section{Experimental part}

The aim of the study

Our paper aimed at assessing the frequency and severity of the hematologic toxicity caused by the cytostatic treatment which was administered according to ALL IC BFM 2002/2009 protocol in the children diagnosed with ALL.

\section{Materials and Methods}

The study included a number of 15 children diagnosed with ALL who were treated from 2008 to 2018 in the Oncopediatrics Department of the $2^{\text {nd }}$ Pediatrics Clinic of the Emergency County Hospital in Craiova, Romania. The patient data were obtained retrospectively from the hospital's information system.

The children were divided into two risk groups according to the ALL IC BFM 2002/2009 protocol: 11 children presented a standard risk (SR) and 4 of them an intermediate risk (IR). Both risk groups (SR and IR) received the same treatment scheme $[8,9]$. 
We excluded, from our study, an infant who was diagnosed with ALL type B with MLL translocation and who presented a high risk and who required a different treatment protocol.

The demographic information of the patients were registered and analyzed; the values of the hematologic parameters were statistically processed (hemoglobin, leukocytes, neutrophils, and thrombocytes).

The study assessed the induction, consolidation and reinduction phases where intense chemotherapy was administered. We studied the toxicity of the administered chemotherapy substances:

- in the induction phases of the remission - Protocol I Phase A (we administered Prednisone, Vincristine, Daunorubicine, L-Asparaginase and Methotrexate intrathecal) and Phase B (Cyclophosphamide, Citarabine, 6- Mercaptopurine, Methotrexate intrathecal);

- in the consolidation phase (protocol M) which used 6Mercaptopurine, Methotrexate in PEV, Methotrexate intrathecal;

- in the re-induction phase of the remission - Protocol II

Phase 1 (Dexamethasone, Vincristine, Adriamycin, LAsparagine) and Phase 2 (Cyclophosphamide, Citarabine, 6- Thyoguanine, Methotrexate intrathecal).

The drug doses, the duration and the mode of administration used during the protocol are presented in table 1.

The grade of toxicity in blood values was classified based on the Common Terminology Criteria for Adverse Events 2010 guideline (table 2) [10].

\begin{tabular}{|c|c|c|}
\hline DRUG & DOSE & DAYS OF ADMINISTRATION \\
\hline $\begin{array}{l}\text { Induction (ProtocolI) } \\
\text { Phase A (SR/IR) } \\
\text { Prednisone (PO) } \\
\text { Vincristine (IV) } \\
\text { Daunorubicin (PI, } 1 \text { hour) } \\
\text { L-Asparaginase (PI, } 1 \text { hour) } \\
\text { Methotrexate (IT)** }\end{array}$ & $\begin{array}{l}60 \mathrm{mg} / \mathrm{m}^{2} / \text { per day } \\
1,5 \mathrm{mg} / \mathrm{m}^{2} / \text { per dose } \\
30 \mathrm{mg} / \mathrm{m}^{2} / \text { per dose } \\
5000 \mathrm{IU} / \mathrm{m}^{2} / \text { per dose } \\
12 \mathrm{mg} \text { per dose }\end{array}$ & $\begin{array}{l}1-28^{\mathrm{a}} \\
8,15,22,29 \\
8,15,22^{\mathrm{b}}, 29^{\mathrm{b}} \\
12,15,18,21,24,27,30,33 \\
1,12\end{array}$ \\
\hline $\begin{array}{l}\text { Induction (ProtocolI) } \\
\text { Phase B (SR/IR) } \\
\text { Cyclophosphamide (PI, 1 hour) } \\
\text { Cytarabine (ARA-C)* (PI, } 1 \text { hour) } \\
\text { 6-Mercaptopurine (PO) } \\
\text { Methotrexate (IT)** }\end{array}$ & $\begin{array}{l}1000 \mathrm{mg} / \mathrm{m}^{2} / \text { per dose } \\
75 \mathrm{mg} / \mathrm{m}^{2} / \text { per dose } \\
60 \mathrm{mg} / \mathrm{m}^{2} / \text { per dose } \\
12 \mathrm{mg} \text { per dose }\end{array}$ & $\begin{array}{l}36,64 \\
(38-41),(45-48),(52-55),(59-62) \\
33-63 \\
45,49\end{array}$ \\
\hline $\begin{array}{l}\text { Consolidation (ProtocolM) } \\
\text { (pre B ALL, SR) } \\
\text { 6-Mercaptopurine (PO) } \\
\text { Methotrexate (PI, 24 hours) } \\
\text { Methotrexate (IT) }\end{array}$ & $\begin{array}{l}25 \mathrm{mg} / \mathrm{m}^{2} / \text { per day } \\
2 \mathrm{~g} / \mathrm{m}^{2} / \text { per dose } \\
12 \mathrm{mg} \text { per dose }\end{array}$ & $\begin{array}{l}1-56 \\
8,22,36,50 \\
8,22,36,50\end{array}$ \\
\hline $\begin{array}{l}\text { Consolidation (ProtocolM) } \\
\text { (pre B ALL IR and T ALL, SR/IR) } \\
\text { 6-Mercaptopurine (PO) } \\
\text { Methotrexate (TV, 24 hours) } \\
\text { Methotrexate (IT)** }\end{array}$ & $\begin{array}{l}25 \mathrm{mg} / \mathrm{m}^{2} / \text { per day } \\
5 \mathrm{~g} / \mathrm{m}^{2} / \text { per dose } \\
12 \mathrm{mg} \text { per dose }\end{array}$ & $\begin{array}{l}1-56 \\
8,22,36,50 \\
8,22,36,50\end{array}$ \\
\hline $\begin{array}{l}\text { Re-induction (Protocol II) } \\
\text { Phase l (SR/IR) } \\
\text { Dexamethasone (PO) } \\
\text { Vincristine (IV) } \\
\text { Adriamycin (IV, } 1 \text { hour) } \\
\text { L-asparaginase (IV, 1 hour) }\end{array}$ & $\begin{array}{l}10 \mathrm{mg} / \mathrm{m}^{2} / \text { per day } \\
1.5 \mathrm{mg} / \mathrm{m}^{2} \\
30 \mathrm{mg} / \mathrm{m}^{2} / \text { per dose } \\
5000 \mathrm{IU} / \mathrm{m}^{2} \text { per dose }\end{array}$ & $\begin{array}{l}1-21^{3} \\
8,15,22,29 \\
8,15,22,29 \\
8,15,22,29\end{array}$ \\
\hline $\begin{array}{l}\text { Re-induction (Protocol II) } \\
\text { Phase 2 (SR/IR) } \\
\text { Cyclophosphamide (PI, 1 hour) } \\
\text { Cytarabine (PI, 1 hour) } \\
\text { 6-Thioguanine (PO) } \\
\text { Methotrexate (IT)** }\end{array}$ & $\begin{array}{l}1000 \mathrm{mg} / \mathrm{m}^{2} / \text { per dose } \\
75 \mathrm{mg} / \mathrm{m}^{2} / \text { per dose } \\
60 \mathrm{mg} / \mathrm{m}^{2} / \text { per day } \\
12 \mathrm{mg} \text { per dose }\end{array}$ & $\begin{array}{l}36 \\
38-41,45-48 \\
36-49 \\
38,45\end{array}$ \\
\hline
\end{tabular}

Table 1

TREATMENT SCHEME OF ALL IC BFM 2009 PROTOCOL

\begin{tabular}{|l|c|c|c|c|}
\hline Age (year) & $<1$ & $1<2$ & $2<3$ & 3 \\
\hline Dosage (mg) & 6 & 8 & 10 & 12 \\
\hline
\end{tabular}

${ }^{*}$ Dosage of IT MTX by age.

PO, orally; IV, intravenous push; PI, intravenous infusion; IT, intrathecally; SR, standard risk group; IR, intermediate risk group; a: Steroid is given up in 9 days by being decreased; ' : Two doses of daunorubicin has been added in IR patients; *: Applied as four days' blocks.

\begin{tabular}{|l|c|c|c|c|}
\hline & Grade 1 & Grade 2 & Grade 3 & Grade 4 \\
\hline Hb (g/dL) & 10 -LLN & $8-10$ & $<8$ & life-threatening anemia \\
\hline $\begin{array}{l}\text { Leukocytes } \\
\left(/ \mathrm{mm}^{3}\right)\end{array}$ & $3000-\mathrm{LLN}$ & $2000-3000$ & $1000-2000$ & $<1000$ \\
\hline ANC(x10/L) & $1.5-\mathrm{LLN}$ & $1-1.5$ & $0.5-1$ & $<0.5$ \\
\hline PLT(x10\%/L) & $75-\mathrm{LLN}$ & $50-75$ & $25-50$ & $<25$ \\
\hline
\end{tabular}

Table 2

TOXICITY CRITERIA ACCORDING TO THE COMMON TERMINOLOGY CRITERIA FOR ADVERSE EVENTS 2010 GUIDELINE 


\section{Results and discussions}

The studied group was made up of 15 children: 11 children had ALL immune phenotype B while the other 4 had ALL immune phenotype T. 11 children presented SR and the other 4 had IR.

The average age for the children diagnosed with ALL was $4.9 \pm 3.9$ years, within the limits of 18 months and 15 years and 9 months. The distribution of the children according to their age was as follows: between 1 and 3 years - 5 children; between 3 and 6 years - 6 children; between 6 and 10 years - 3 children, over 10 years -1 child. Among the 15 children with ALL who were part of our study 11 were boys and 4 girls.

The origin area of the children was urban in 10 and rural in 5. Their residence county was: Dolj 7 children, Olt 6 children, Valcea 1 child, and Gorj 1 child (table 3).

The studied group contained 11 children with ALL immune phenotype $B$ and 4 children with ALL immune phenotype T (table 3).

We distributed the cases taking into account their grade of severity, according to the Common Terminology Criteria for hemoglobin, leucocytes, neutrophils, and thrombocytes.

The case distribution according to the grades of severity (G) of the studied hematologic parameters revealed the following:

- for the $\mathrm{Hb}$ values we registered: $\mathrm{Gl}$ in 2 children, $\mathrm{G} 2$ in 4 children, G3 in 6 children and G4 in 3 children;

- for the leukocytes values: G1 in 3 children, G2 in 5 children, G3 in 3 children, and G4 in 4 children;

- for the ANC values: $G 1$ in 2 children, $G 2$ in 3 children,

$\mathrm{G} 3$ in 3 children, and $\mathrm{G} 4$ in 7 children;

- for the thrombocytes values: G1 in 4 children, G2 in 6 children, G3 in 4 children, and G4 in 1 child (table 4).
The mean values for the $\mathrm{Hb}$ were $7.3 \pm 2.7 \mathrm{~g} / \mathrm{dl}$ in Protocol I, Phase A, $7.8 \pm 1.96 \mathrm{~g} / \mathrm{dL}$ in Phase B; $9.7 \pm 1.2 \mathrm{~g} /$ $\mathrm{dL}$ in Protocol M; $10.2 \pm 1.5 \mathrm{~g} / \mathrm{dL}$ in Protocol II Phase 1 and $9.9 \pm 2.1 \mathrm{~g} / \mathrm{dL}$ in Phase 2 .

The mean values for the leukocytes were $2.92 \pm 1.04$ $\times 10^{\circ} / \mathrm{L}$ in Protocol I, Phase A, $2.14 \pm 0.85 \times 10^{9} / \mathrm{L}$ in Phase B; $3.21 \pm 1.12 \times 10^{\circ} / \mathrm{L}$ in Protocol M; $4.02 \pm 2.03 \times 10^{9} / \mathrm{L}$ in Protocol II Phase 1 and $2.32 \pm 1.76 \times 10^{\circ} / \mathrm{L}$ in Phase 2.

The mean values for the Absolute Neutrophil Count (ANC) were $0.85 \pm 0.52 \times 10^{\circ} / \mathrm{L}$ in Protocol I, Phase $\mathrm{A}, 0.76$ $\pm 0.27 \times 10^{\circ} / \mathrm{L}$ in Phase B; $3.2 \pm 1.8 \times 10^{\circ} / \mathrm{L}$ in Protocol M; $3.9 \pm 2.8 \times 10^{9} / \mathrm{L}$ in Protocol II Phase 1 and $1.1 \pm 0.9 \times 10^{\%}$ $L$ in Phase 2.

The mean values for the platelet count (PLT) were 102.7 $\pm 82.3 \times 10^{9} / \mathrm{L}$ in Protocol I, Phase A, $132.3 \pm 72.4 \times 10^{9} / \mathrm{L}$ in Phase B; $203.6 \pm 87.5 \times 10^{9} / \mathrm{L}$ in Protocol M; $198.7 \pm 72.3$ $\times 10^{\circ} / \mathrm{L}$ in Protocol II Phase 1 and $163.8 \pm 82.5 \times 10^{9} / \mathrm{L}$ in Phase 2.

The mean values ( $\pm D S$ ) for the hematologic parameters, according to the treatment phases of the BFM 2002/2009 protocol were registered in table 5 .

Anticancer chemotherapies are responsible for numerous adverse events. Among these, hematologic toxicity is one of the main causes for ending treatment.

These toxicities decrease production of red blood cells (anemia), production of white blood cells (neutropenia or granulocytopenia), and production of platelets (thrombocytopenia) which may be life-threatening to the patient [4].

Most of the children diagnosed with ALL were males (11/15). The average age of the children when diagnosed with ALL was $4.9 \pm 3.9$ years, between the interval 18 months and 15 years and 9 months, most of the cases being registered in the age group of 3-6 years (6/15).

\begin{tabular}{|l|c|c|c|}
\hline Demographic data & $\begin{array}{c}\text { Number of } \\
\text { patients }\end{array}$ & Demographic data & $\begin{array}{c}\text { Number of } \\
\text { patients }\end{array}$ \\
\hline Sex & 11 & $\begin{array}{c}\text { Average age when } \\
\text { diagnosed }\end{array}$ & $4.9 \pm 3.9$ years \\
Male & 4 & Origin area & \\
Female & & Urban & 10 \\
\hline Age distribution & 5 & Rural & 5 \\
1-3 years & 6 & & \\
3-6 years & 3 & & \\
6-10 years & 1 & & \\
over 10 years & & & \\
\hline
\end{tabular}

Table 3

DEMOGRAPHIC DATA OF THE PATIENTS INCLUDED IN THE STUDIED GROUP

CASE DISTRIBUTION ACCORDING TO THE SEVERITY GRADES (G) OF THE HEMATOLOGIC PARAMETERS

\begin{tabular}{|l|c|c|c|c|}
\hline $\begin{array}{l}\text { Hematologic } \\
\text { parameters }\end{array}$ & $\begin{array}{c}\text { Number of patients } \\
\text { Grade 1 }\end{array}$ & $\begin{array}{c}\text { Number of patients } \\
\text { Grade 2 }\end{array}$ & $\begin{array}{c}\text { Number of patients } \\
\text { Grade 3 }\end{array}$ & $\begin{array}{c}\text { Number of patients } \\
\text { Grade 4 }\end{array}$ \\
\hline Hb (g/dL) & 2 & 4 & 6 & 3 \\
\hline Leukocyte (x10\%) & 3 & 5 & 3 & 4 \\
\hline ANC(x10\%) & 2 & 3 & 3 & 7 \\
\hline PLT(x10\%) & 4 & 6 & 4 & 1 \\
\hline
\end{tabular}

Table 5

MEAN VALUES FOR THE HEMATOLOGIC PARAMETERS, ACCORDING TO THE TREATMENT PHASES OF THE BFM 2002/2009 PROTOCOL

\begin{tabular}{|l|c|c|c|c|}
\hline \multirow{2}{*}{ Protocol } & \multicolumn{4}{|c|}{ Hematologic parameters } \\
\cline { 2 - 5 } & $\mathrm{Hb}(\mathrm{g} / \mathrm{L})$ & Leukocyte (x10\%/L) & ANC(x10\%/L) & PTL(x10\%/L) \\
\hline IPhase A & $7.3 \pm 2.7$ & $2.92 \pm 1.04$ & $0.85 \pm 0.52$ & $102.7 \pm 82.3$ \\
I Phase B & $7.8 \pm 1.96$ & $2.14 \pm 0.85$ & $0.76 \pm 0.27$ & $132.3 \pm 72.4$ \\
\hline M & $9.7 \pm 1.2$ & $3.21 \pm 1.12$ & $3.2 \pm 1.8$ & $203.6 \pm 87.5$ \\
\hline II Phase 1 & $10.2 \pm 1.5$ & $4.02 \pm 2.03$ & $3.9 \pm 2.8$ & $198.7 \pm 72.3$ \\
II Phase 2 & $9.9 \pm 2.1$ & $2.32 \pm 1.76$ & $1.1 \pm 0.9$ & $163.8 \pm 82.5$ \\
\hline
\end{tabular}


The registered immune phenotype was predominantly B (11/15), while de risk group was mainly SR.

The children were treated according to the BFM 2002 protocol until 2011 and according to BFM 2009 protocol until the end of 2018.

The most severe hematologic toxicity (G4) was registered for neutrophils (7/15 children) during the induction and re-induction periods; in 3 children during the Protocol I, Phase A, in 2 children during Protocol I, Phase B, and in 2 children during Protocol II, Phase 2; 5 of these children presented an episode of febrile neutropenia and 4 of them accused severe infections (1 pneumococcal sepsis with otoantritis, 1 sepsis with Staphylococcus aureus and otoantritis with Klebsiella, 2 had whitlow). Other 2 children with severe neutropenia presented severe mucositis.

For the leukocytes count, G4 of severity was registered in 4 children ( 2 during Protocol IA, 1 during Protocol IB and 1 during Protocol II2).

The hemoglobin values most frequently showed grade 3 of severity during the remission induction period (with values between 6.5 and $7.9 \mathrm{~g} / \mathrm{dL}$ ) in 6 children, requiring transfusions of red blood cells concentrates. Grade 4 of severity for hemoglobin was registered in 3 children.

The platelets count showed that grade 2 of severity was the most frequent (50-74.9x 10\% $/ \mathrm{L})$ - in 6 children out of 15 ;

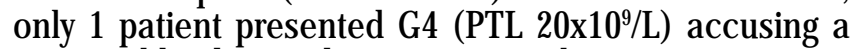
mucosa bleeding and was given a substitution treatment with thrombocyte concentrates.

The chemotherapy toxicity remains a problem, while the hematologic toxicity has major consequences upon the disease evolution. The most frequent toxic adverse reaction is represented by neutropenia. This may lead to serious infections, which prove difficult to treat. Anemia and thrombocytopenia often occur during the cytostatic treatment.

They will require blood product transfusions which, at their turn, will generate other possible complications (allergic reactions, infections) [11-14].

The combination therapy with cytostatic agents having different action mechanisms and toxicity grades is often necessary in order to avoid the destruction following the limited logarithmic monotherapy. If the used agents do not have a similar toxicity, they can be used in scheme combinations for dosages which have an approximately equal toxicity to those used in monotherapy [15-42].

Stating the hematologic toxicity differs from one case to another and depends on the used agents, the administered dosages, the way of administration; it is also influenced by the therapeutic antecedents (previous cytotoxic chemotherapy, applied therapeutic strategy and the biologic status of the patient) [17-19].

Medullary aplasia represents the most dangerous picture which may occur after chemotherapy and its seriousness is given by the possibility for an infectious clinical picture to occur, which may lead to septicemia, to a hemorrhagic syndrome or to mucosal lesions associated with hemorrhage and necrosis [7-19].

We did not register any death during our study.

\section{Conclusions}

The most severe hematologic toxicity (grade 4 of severity) was registered for neutrophils ( $7 / 15$ children) within the induction and re-induction periods.

The lowestabsolute value of the number of neutrophils was $0.76 \pm 0.27 \times 10 \mathrm{y} / \mathrm{L}$ in phase B, Protocol I. 5 of these 7 children presented an episode of febrile neutropenia, 4 of them accusing severe infections.
Grade 4 of severity was registered in 4 children for the leukocyte number.

The hemoglobin values showed that grade 3 of severity was the most frequent in the remission induction periods.

The thrombocytes count showed that grade 2 of severity was the most frequent ( 6 out of 15 patients); only one

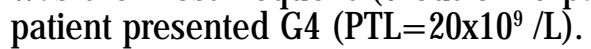

\section{References}

1. ANSARI, M., ST-ONGE, G., KRAI INOVIC, M., Pharmacogenomics of acute lymphoblastic leukemia, Med Sci (Paris), 23, 11, 2007, p. 961967.

2. ***SEER Cancer Statistics Review, National Cancer Institute. Bethesda, MD. https://seer.cancer.gov/csr/1975_2015/.

3. GAYNON, P.S., ANGIOLILLO, A.L., CARROLL, W.L., et al. Long-Term Results of the Children's Cancer Group Studies for Childhood Acute Lymphoblastic Leukemia 1983-2002: A Children's Oncology Group Report. Leukemia, 24, 2010, p. 285-297.

4. STEVENS, G.M, CARON, N.H., BIONDI, A. Cancer in children. Clinical Management. Sixth edition. Oxford University Press ISBN 978-0-19959941-7, 2012, p. 161-173.

5. KISHI, S., CHENG, C., FRENCH, D., et al. Ancestry and pharmacogenetics of antileukemic drug toxicity. Blood, 109, 10, 2007, p. 4151-4157.

6. KRAJINOVIC, M., LABUDA, D., SINNETT, D., Childhood acute lymphoblastic leukemia: genetic determinants of susceptibility and disease outcome. Rev Environ Health, 16, 4, 2001, p. 263-279.

7. BADULESCU, F., VOICU, V., POP, L., BADULESCU, A., Vademecum de chimioterapie antineoplazica, editura Medicala, Bucuresti, ISBN 973-39-0376-0, 1999, p. 295-348.

8. STARY, J., ZIMMERMANN, M., CAMPBELL, M., et al. Intensive chemotherapy for childhood acute lymphoblastic leukemia: results of the randomized intercontinental trial ALL IC-BFM 2002.J Clin Oncol, 32, 3, 2014, p.174-184.

9. *** https://www.researchgate.net/figure/ Treatment-scheme-of-ALLIC-BFM-2009-Protocol_tbI2_319401549.

10. *** U.S. National Institutes of Health. National Cancer Institute CTEP CTCAE v3.0. 2011. https://ctep.cancer.gov/protocoldevelopment/ electronic_applications/ctc.htm.

11. YILMAZZ, S., OREN, H., DEMIRCIOĐLU, F., et al. Assessment of Febrile Neutropenia Episodes in Children with Acute Leukemia Treated with BFM Protocols. Pediatric Hematology and Oncology, 25, 2008, p. 195-204.

12. RYTWINSKI, K., SONTA-JAKIMCZYK, D., KONOPACKA, M., CIECHANOWSKA, U. Anemia and recurrences in acute lymphoblastic leukemia in children after the treatment and the frequency of the erythroblasts with micronuclei, Acta Haematol Pol, 23, 2, 1992, p.9599.

13. J AIME-PEREZ, J.C., GARCIA-ARELLANO, G., HERRERA-GARZA, J.L., MARFIL-RIVERA, L.J., GOMEZ-ALMAGUER, D. Revisiting the complete blood count and clinical findings at diagnosis of childhood acute lymphoblastic leukemia: 10-year experience at a single center. Hematol Transfus Cell Ther., 41, 1, 2019, p. 57-61.

14. MCATEE, C.L., SCHNELLER, N., BRACKETT, J., BERNHARDT, M.B., SCHAFER, E.S. Treatment-related sinusoidal obstruction syndrome in children with de novo acute lymphoblastic leukemia during intensification. Cancer Chemother Pharmacol., 80, 6, 2017, p. 12611264.

15. YANG, L, YU, L., CHEN, X, HU, Y., WANG, B. Clinical Analysis of Adverse Drug Reactions between Vincristine and Triazoles in Children with Acute Lymphoblastic Leukemia. Med Sci Monit., 21, 2015, p. 1656-1661.

16. PAPADANTONAKIS, N, ADVANI, AS. Recent advances and novel treatment paradigms in acute lymphocytic leukemia. Ther Adv hematol, 7, 5, 2016, p. 252-269.

17. *** OZDEMIR, Z.C., KAR, Y.D., TURHAN, A.B., BOR, O. Assesment of Hematological Toxicity in Children with Acute Lymphoblastic 
Leukemia, receiving Treatment with ALL IC-BFM 2009 Protocol. Open Access Library J ournal 2017, vol 4, e3807, ISSN 2333-9705.

18. TEWARI, D., RAWAT, P., SINGH, P.K. Adverse drug reactions of anticancer drugs derived from natural sources. Food Chem Toxicol, 123, 2019, p. 522-535.

19. TESTART-PAILLET, D., GIRARD, P., et al. Contribution of modeling chemotherapy-induced hematological toxicity for clinical practice. Critical Reviews in Oncology/Hematology, 63, 2007, p. 1-11.

20. PUIU, I.,ALBU, C.V., TARTEA, E.A., CALBOREAN, V., GHEORMAN, V., DINESCU,S.N., VASILE,R.C., DINESCU,V.C., BICA, E.C., ROMANESCU, F.M., TUDORASCU,D.R. Relationships Between Glial Enteric Cells, Beta-cell Signaling and Tumor Proliferative Activity in Patients with Colorectal Neoplasia, Rev Chim (Bucharest), 69, no 10, 2018, p. 27442748.

21.GHEORMAN,V., CHIRITA,A.L., DUMITRESCU,E.M., ROGOVEANU,I., ISTRATOAIE, O., GHEORMAN,V., PANA,R.C. Particularities of associating viral hepatitis with pregnancy and mental disorders, Rom J Morphol Embryol 2016, 57(1): 45-50.

22. CALBOREAN,V., GHEORMAN,V., AL NAMAT, R., CAZACU,I. M., VARJU,P., GEDE, N., STREBA,T.C., VERE, C.C., GHEONEA,D.I., GHEORMAN, V., LUNGULESCU, C., LUNGULESCU, C.,V. The Association Between Stress Level and Laboratory Parameters, Sex, Age and Stage Disease in Patients with Digestive and Bronchopulmonary Neoplasms, Rev Chim (Bucharest), 68, no 12, 2017, p.3010-3014.

23. ENE, C.G., ROSU,A., GHEORMAN,V., CALBOREAN,V., TENEA COJAN,T.S., ROGOVEANU,O.C., VLADU,M.I., RADU, L. Incidence of Osteoporosis and the Risk of Fracture in Patients with Rheumatoid Arthritis Undergoing Corticosteroid Treatment, Rev Chim (Bucharest), 69, no 7, 2018, p.1851-1854.

24. VLADU, I.M., RADU,L., GIRGAVU ,S.R., TENEA COJAN, T.S., ENE ,C.G., CALBOREAN , V., GHEORMAN ,V., CLENCIU,D. Alteration of Glucidic Metabolism in Relation with Visceral Adiposity Index, Rev Chim (Bucharest), 69, no 9, 2018, p.2479-2481.

25. BALEANU, V.D., CONSTANTIN, D.V ., PASCAL, A ., ALEXANDRU, D.O., BOBIC, S., SOCEA, B ., MANDA, A.L., DAVITOIU, D., DIJ MARESCU, A.L., GEORGESCU, I., MIREA, C.S. Use of Synthetic Protetic Materials in Surgical Abdominal Defects Analysis of the Advantages and Lack of the Liechtenstein Method. Rev Chim (Bucharest), 69,no 7, 2018, p 1740-1743.

26. NOVAC, M.V., NICULESCU, M., MANOLEA, M.M., DIJ MARESCU, A.L., ILIESCU, D.G., NOVAC,M.B., ROTARU,L.T, STOENESCU, M.F., TABACU, M.C., TUDORACHE, S., BUSUIOC, C.J . , GHEONEA, I.A. Placental findings in pregnancies complicated with iugrhistopathological and immunohistochemical analysis. Rom J Morphol Embryol , 2018, vol 59, p. 715-720.

27. STOENESCU, V.E., NICULESCU, M., NOVAC, L., MANOLEA, M.M., TOMESCU, P.I., DIJ MARESCU, A.L., NOVAC, M.B., TUDORACHE, S., ILIESCU, D.G . Immunohistochemical reaction of the glandular epithelium in endometrial hyperplasia compared to endometrial carcinoma. Rom J Morphol Embryol , 2017, vol 58, 791800.

28. SIMINEL, M.A., GHEONEA, C., STANESCU, M.R., COMANESCU, A.C. , DIJ MARESCU, A.L., NEAMTU, S.D., COTOI, B.V., NEDELCUTA, R.M., NICULESCU, E.C. Velamentous insertion of the umbilical cord vessels with vasa praevia - a case report .Rom J Morphol Embryol, 2015, vol 56, 301-308.

29. BUICU, G.E., GRECU, M.G., SALCUDEAN, A., GRECU, I.G., MARINESCU, C., NIRESTEAN, A., TURLIUC, S., HADAREANU, V., UDRISTOIU, I. Evaluation of elder physical abuse. EUROPEAN PSYCHIATRY, 41, 2017, p S583-S584.
30.CHIMORGIACHIS,A.,CONSTANTIN,M.D.G.,UDRISTOIU,T., PIRLOG, M.C.,UDRISOIU,I. Weight gain in patients with schizophrenia and atypical antipsychotic treatment - neurobiological correlations. JOURNAL OF NEURAL TRANSMISSION, 114, issue 7, 2007, p. CXXCXX.

31. TRASCA, S.P., FLORESCU, C., DINESCU, V.C., PUIU, I., DINESCU, S.N., TUDORASCU, D.R., BICA, C., VASILE, R.C., ROMANESCU, F.M., BUNESCU, M.G., CIOATERA, N., GOANTA, E.V. The Assessment of Percutaneous Coronary Angioplasty versus Coronary Artery Bypass Grafting in Treatment of Left Main Coronary Artery Disease. Rev Chim (Bucharest), 2018, 69, nr.12, p. 3600-3604.

32. CALBOREAN, V., GHEORMAN, V., CONSTANTIN, C. ISTRATOAIE, O.j ournal of Cardiovascular Emergencies, 2018, 4, nr.2, p. 101-105. 33. PETRESCU, I.O., PLESEA, I.E., FOARFA, M.C., BONDARI, S., SINGER, C.E., DUMITRESCU, E.M., PANA, R.C., STÃNESCU, G.L., CIOBANU, M.O. Rare thymic malignancy of B-cell origin - T-cell $\div$ histiocyte-rich large B-cell lymphoma. Rom J Morphol Embryol, 57, 3, 2016, p.10751083.

34. MARINAU, L.D., SINGER, C.E., MESINA, C., NICULESCU, E.C., PUIU, I., PETRESCU, I.O., GEORMANEANU, C., ENCULESCU, A.C., TACHE, D.E., PURCARU, S.O., RACIULA, S., DAMIAN, C.L. Two girl patients with medulloblastoma. Case reports. Rom J Morphol Embryol, 58, 3, 2017, p. 1103-1108.

35. POPESCU, M., POPESCU, I.A., STANCIU, M., CAZACU, S.M., IANOSI, N.G., COMANESCU, M.V., SINGER, C.E., NEAGOE, C.D. Non-alcoholic fatty liver disease - clinical and histopathological aspects. Rom J Morphol Embryol, 57, 4, 2016, p. 1295-1302.

36. SINGER, C.E., COSOVEANU, C.S., CIOBANU, M.O., STOICA, G.A., PUIU, I., GRUIA, C.L., STREBA, L., CONSTANTIN, C., NEAGOE, C.D. Hirschprung's disease in different settings - a series of three cases from a tertiary referral center. Rom J Morphol Embryol, 56, 3, 2015 p. 1195-200.

37. MIHAILOVICI, A.R., DELIU, R.C., MARGARITESCU, C., SIMIONESCU, C.E., DONOIU, I., ISTRATOAIE, O., TUDORASCU, D.R., TARTEA, E.A., GHEONEA, D.I. Collagen I and III, MMP-1 and TIMP-1 immunoexpression in dilated cardiomyopathy. Rom J Morphol Embryol, 58, 3, 2017, p. 777-781.

38. PUIU, I., ALBU, C.V., TARTEA, E.A., CALBOREAN, V., GHEORMAN, V., DINESCU, S.N., VASILE, R.C., DINESCU, V.C., BICA, E.C., ROMANESCU, F.M., TUDORASCU, D.R. Relationships Between Glial Enteric Cells, Beta-cell Signaling and Tumor Proliferative Activity in Patients with Colorectal Neoplasia. Rev. Chim. (Bucharest), 69, no. 10,2018, p.2461-2464.

39. CALBOREAN, V., GHEORMAN, V., OCTAVIAN, I., MUSTAFA, R.E., COJ OCARU, P.A., ALEXANDRU, D.O., GALCEAVA, O., MITA, A.,MISCOCl, S.A., AL NAMAT, R., GHEONEA,D.I. QT interval analysis in patients with chronic liver disease, Rev. Chim. (Bucharest), 69, no. 5, 2018, p.1134-1138.

40. CALBOREAN, V., CIOBANU, D., MIREA, S.C., GALCEAVA, O.,GHEORMAN, V., PADUREANU, V., FORTOFOIU, C.M., FORTOFOIU,M., MITA, A., DINESCU, S.N., MISCOCI, S.A., DINESCU, V.C. Benefit of Cardiac Resynchronization Therapy in Patients with Heart Failure. Rev. Chim. (Bucharest), 69, no. 9, 2018, p.2761-2764. 41. CALBOREAN, V., MISCOCI, S. A., ISTRATOAIE, O., GALCEAVA, O.,ALEXANDRU, D.O., GUTA, M.M., GHEORMAN, V., PADUREANU, V., FORTOFOIU, C.M., DIJMARESCU, A.L., GHEONEA, D.I., Correlation Between Liver Cirrhosis and Risk of Cardiac Arrhythmias, Rev Chim(Bucharest), 69, no 6, 2018, p. 1527-1532.

42. GHEORMAN,V., MILITARU., CALBOREAN,V., GHEORMAN, L.M.,CHIRITA, A.L., MITA, A., GALCEAVA, O., GHEORMAN, V., STANCA, D.,UDRISTOIU, I., Clinical and biochemical consideration regarding stress and arrhytmic risk in patients with chronic viral liver diseases, Rev Chim. (Bucharest), 69, no. 4, 2018, p.881-885.

Manuscript received: 14.11 .2018 